across one's. life and it threw the great matters of life, if only mamentarily, into proper perspective. The substantial was revealed as substantial, the trivial as trivial and we were privileged, for a short time, to put the latter aside. That death also made clear the high relevance of the virtues that Kennedy admired and that he himself possessed. For it was an act of sudden violence and seeming futility that brought about the death of a man who epitomized the use of reason, patience, moderation, a man who emphasized the strength and the fragility of the measures that sustain our national life, and indeed the lives of millions around the world. His constant effort was to restrain the lawless, the possibly violent, whether the threat was domestic or foreign. Now that those major threats survive him almost undiminished, we may more neariy comprehend the undramatic virtues, the largely undramatic and sometimes ineffective measures, by which he sought to contain them.

His emphasis upon restraint and moderation was evident in many of his statements. In his "Strategy for Peace," for example, he said, "I speak of peace, therefore, as the necessary rational end of rational men. I realize that the pursuit of peace is not as dramatic as the pursuit of war, and frequently the words of the pursuer fall on deaf ears. But we have no more urgent task." This peace, he added, would be a "peace, based not on a sudden revolution in human nature but on a gradual evolution in human institu. tions-on a series of concrete actions and effective agreements which are in the interest of all concerned. There is no single, simple key to this peace, no grand or magic formula to be adopted by one or two powers.... For peace is a process, a way of solving problems."

And he was impressive, too, because he spoke -as could the leader of no other world poweras a person who was raised and hardened in a newer age. "Let the word go forth from this time and place, to friend and foe alike, that the torch has been passed to a new generation of Americans-born in this century, tempered by war, disciplined by a hard and bitter peace, proud of our ancient heritage - and unwilling to witness or permit the slow undoing of those human rights to which this nation has always been committed, and to which we are committed today at home and around the world."

He proved himself to be an exemplar of this new generation, displaying under pressure poise and wit, intelligence and directness. In addition, his young staff, his own physical grace, an attractive wife and young children all helped to make him a spokesman for youth and untried hopes around the worid.

How this rare combination of abilities, qualities and circumstances will be assessed by history, which winnows and weighs without compassion, one cannot know. President Kennedy's record is not a full rounded thing but an untimely fragment with high spots and low, with more of promise than accomplishment. John F. Kennedy's personal characteristics did not win the allegiance of all and their vivid quality will pass with the memories of living men. Yet one can say with confidence that there was greatness in him and that his name will be sweet in history. We, who are diminished by his death, mourn for him.

\section{A CONTINUATION AND A BEGINNING}

"Life is for the living," the late President said, and President Lyndon Johnson has moved rapidly from the wings to front-stage center, from the shadows of relative inconsequence to the floodlights of world attention. He is now the central actor on our political scene and the quality of our lives will be strongly affected by his decisions.

Full-scale assessments of President Johnson's intellectual and temperamental abilities will soon be surfeit. His own initial addresses are sufficient, however, to indicate the qualities we may expect. The awesome pressures of the Presidency, it is frequently noted, shape into a new if still recognizable form the person who attains that office. They also do much to shape the public response to that person. Both effects were evident when President Johnson gave his first address. Eloquent, deliberate and confident, it impressed even those who had known Senator Johnson for years.

But his next address made definite what was already expected-that the beginning of President Johnson's term will be a continuation of his predecessor's program. This is determined partly by the very intricacy of the decision-making complex that was established during the last several years, partly to the short time the President will hold office before the next election, and partly also to the sound, clearly formulated goals that he has inherited. 